\title{
Wild-type p53 mediates apoptosis by E1A, which is inhibited by E1B
}

\author{
Michael Debbas ${ }^{1}$ and Eileen White $\mathrm{e}^{1-3}$ \\ ${ }^{1}$ Center for Advanced Biotechnology and Medicine and ${ }^{2}$ Department of Biological Sciences, Rutgers University, Piscataway, \\ New Jersey 08854 USA
}

\begin{abstract}
Transformation of primary rodent cells by the adenovirus E1A and E1B oncogenes is a two-step process, where E1A-dependent induction of proliferation is coupled to E1B-dependent suppression of programmed cell death (apoptosis). The E1B gene encodes two distinct transforming proteins, the 19K and 55K proteins, both of which independently cooperate with E1A. E1B $19 \mathrm{~K}$ or $55 \mathrm{~K}$ protein, or the human Bcl-2 protein, functions to suppress apoptosis and thereby permits transformation with E1A. The E1B 55K protein blocks p53 tumor suppressor protein function, indicating that p53 may mediate apoptosis by $\mathrm{E} 1 \mathrm{~A}$. In the mutant conformation, p53 blocked induction of apoptosis by E1A and efficiently cooperated with E1A to transform primary cells. When p53 was returned to the wild-type conformation, E1A + p53 transformants underwent cell death by apoptosis. This induction of apoptosis by conformational shift of p53 from the mutant to the wild-type form was inhibited by expression of the E1B $19 \mathrm{~K}$ protein. Thus, the p53 protein may function as a tumor suppressor by initiating a cell suicide response to deregulation of growth control by E1A. E1B 19K and 55K proteins provide separate mechanisms that disable the cell suicide pathway of p53.
\end{abstract}

[Key Words: Apoptosis; E1A; E1B; p53, oncogenes; tumor suppressor genes]

Received December 16,1992; revised version accepted January 21,1993.

The ElA gene products interact with and perturb the function of key regulators of cell growth, such as the retinoblastoma protein (Whyte et al. 1988) and cyclin A (Pines and Hunter 1990). The sum of these interactions is induction of proliferation (Stabel et al. 1985; Kaczmarek et al. 1986) but also viability loss, intranucleosomal DNA fragmentation, and chromatin condensation (White et al. 1991,1992; Rao et al. 1992), all hallmarks of apoptosis (Wyllie 1980). Thus, induction of apoptosis by E1A may impede transformation despite the ability of E1A to recruit cells into a proliferative state. Evidence to support this scenario has come from the observations that inhibitors of apoptosis, the E1B $19 \mathrm{~K}$ or the Bcl-2 proteins, will cooperate with E1A to transform primary cells (Rao et al. 1992; White et al. 1992).

The E1B 19K protein was originally identified as an inhibitor of DNA fragmentation and cell death in human cells productively infected with adenovirus. Adenovirus mutants that fail to express a functional E1B 19K gene product induce pronounced fragmentation of both viral and cellular DNA (Pilder et al. 1984; Takemori et al. 1984; White et al. 1984b), causing premature death of the host cell, which severely compromises virus yield (Pilder et al. 1984; Subramanian et al. 1984; White et al. 1984b,1991; White and Stillman 1987). These findings established a role for the E1B $19 \mathrm{~K}$ protein as a cell survival maintenance factor required to prevent cell death triggered by adenovirus infection of human cells.

\footnotetext{
${ }^{3}$ Corresponding author.
}

The viral gene product responsible for eliciting the induction of DNA fragmentation in E1B 19K mutant virusinfected cells mapped to the ElA gene /White and Stillman 1987; White et al. 1991). Therefore, the E1B 19K protein acts to compensate for the cytotoxic consequences of E1A function. Because DNA fragmentation is an indicator of cell death by apoptosis, ElA was thought to induce apoptosis and the ElB $19 \mathrm{~K}$ protein was believed to function as an inhibitor of apoptosis (White et al. 1991). These conclusions were substantiated by the findings that expression of the E1B 19K protein could block cell death induced by such heterologous agents as tumor necrosis factor- $\alpha$ (TNF- $\alpha$ ) and Fas antigen (Gooding et al. 1991; Hashimoto et al. 1991; White et al. 1992), both of which are potent inducers of apoptosis (Laster et al. 1988; Itoh et al. 1991/. Genetic analysis of a series of E1B 19K mutant proteins has shown that inhibition of TNF- $\alpha$ cytolysis and transforming activity cosegregate, consistent with both activities resulting from the same function, inhibition of apoptosis (White et al. 1992). By blocking apoptosis the E1B 19K protein may not only directly promote survival of infected cells but also may provide the additional advantage of permitting escape antiviral immune surveillance directed by TNF- $\alpha$ and Fas. Thus, the E1A and E1B gene products provide a model system for examining both positive and negative regulation of apoptosis.

Regulation of apoptosis may be of general importance in transformation and may not be limited to our observations with the transforming genes of adenovirus. The 
human $b c l-2$ proto-oncogene that becomes overexpressed as a result of translocation in human B-cell lymphomas has been shown to be an inhibitor of apoptosis. Bcl-2 is a mitochondrial protein that, when overexpressed, will block apoptosis in response to growth factor withdrawal in dependent lines (Vaux et al. 1988; Hockenbery et al. 1990; Nuñez et al. 1990|, glucocorticoid treatment, radiation, and anti-CD3 antibodies (Sentman et al. 1991; Alnemri et al. 1992). In transgenic mouse models Bcl-2 overexpression will extend B-cell memory (Nuñez et al. 1991) and cause lymphomas (McDonnell and Korsmeyer 1991; Strasser et al. 1991). Finally, expression of the human $b c l-2$ proto-oncogene will substitute for ElB in a transformation assay with ElA (Rao et al. 1992). Therefore, apoptosis is a significant obstacle to transformation by ElA, which can be overcome in multiple ways by the $19 \mathrm{~K}, 55 \mathrm{~K} \mathrm{E} 1 \mathrm{~B}$, or Bcl-2 protein.

Although the mechanism by which the E1B $19 \mathrm{~K}$ or $\mathrm{Bcl}-2$ protein suppresses apoptosis is not known, the E1B $55 \mathrm{~K}$ protein, which inhibits the function of the p53 tumor suppressor gene product (Sarnow et al. 1982; Yew and Berk 1992), also was able to suppress apoptosis and cooperate with ElA (Rao et al. 1992). This suggested that p53 may participate in the apoptosis pathway and that elimination of p53 function may block apoptosis.

p53 mutations producing loss of p53 function are among the most common genetic alterations found in human cancer (Vogelstein 1990; Levine et al. 1991). The mechanism by which p53 functions as a tumor suppressor is therefore central to preventing oncogenic transformation. When reintroduced into stable, transformed cell lines that have lost p53 function, wild-type p53 most often produces growth arrest at the $G_{1} / S$ boundary, suggesting a role for $\mathrm{p} 53$ in regulating cell cycle progression (Finlay et al. 1989; Diller et al. 1990; Mercer et al. 1990; Michalovitz et al. 1990; Ginsberg et al. 1991b; Martinez et al. 1991). In some situations, however, reintroduction of wild-type p53 produces apoptosis, suggesting a role for p53 in induction of cell suicide (Yonish-Rouach et al. 1991; Shaw et al. 1992). To test the involvement of p53 in E1A-dependent apoptosis, the murine p53(val135) temperature-sensitive mutant (pLTRcGval135) (Michalovitz et al. 1990) was utilized in transformation assays with primary baby rat kidney (BRK) cells. Expression of mutant p53 was sufficient to block apoptosis by E1A and permit transformation with high frequency. When p53 was returned to the wild-type conformation, ElA + p53 transformants underwent apoptosis. Expression of the E1B $19 \mathrm{~K}$ protein completely prevented induction of apoptosis by wild-type p53. Therefore, p53 function is required for induction of apoptosis by E1A, and the E1B $19 \mathrm{~K}$ protein has been identified as an inhibitor of $\mathrm{p} 53$ function.

\section{Results}

\section{E1A and mutant p53 cooperate to transform primary rodent cells}

In primary BRK cells E1A expression is sufficient to initiate the formation of foci, most of which subsequently degenerate and die. Transformants emerge with low frequency under these circumstances. When ElA is cotransfected with either E1B $19 \mathrm{~K}$ or $55 \mathrm{~K}$ expression vectors, transformation occurs with high frequency (Fig. 1; White and Cipriani 1990; Rao et al. 1992; White et al. 1992). Although the mechanism by which the E1B $19 \mathrm{~K}$ protein functions to suppress apoptosis was not known, the ability of the E1B $55 \mathrm{~K}$ protein to do so suggested the involvement of $\mathrm{p} 53$. To test the role of $\mathrm{p} 53$ in induction of apoptosis following E1A expression, the p53(val135) temperature-sensitive mutant was used.

The p53(val135) protein behaves as a dominant-interfering mutant at the restrictive temperature $\left(37.5^{\circ} \mathrm{C}\right)$ and reverts to the wild-type conformation at the permissive temperature $\left(32^{\circ} \mathrm{C}\right)$. Primary BRK cells were transfected with E1A and mutant p53|vall35) to test whether the blocking of p53 function would suppress E1A-dependent apoptosis. The frequency-of-focus formation by ElA was 10-fold less in the absence of the E1B 19K gene owing to the induction of cell death and focus regression as reported previously (Fig. 1; Rao et al. 1992; White et al. 1992). Mutant p53(val135) enhanced the transformation frequency at least 10 -fold over $\mathrm{E} 1 \mathrm{~A}$ alone at the restrictive temperature (Fig. 1). Cooperation between mutant p53 and E1A was so efficient that it was the most potent transforming combination we have observed in this assay. No focus formation was detectable when mutant p53 was transfected alone or in combination with the E1B 19K expression vector (Fig. 1).

Transformed cell lines were generated from $\mathrm{E} 1 \mathrm{~A}+\mathrm{p} 53$ (val135)-transformed foci at the restrictive temperature. All E1A + p53|val135| transformants ex-

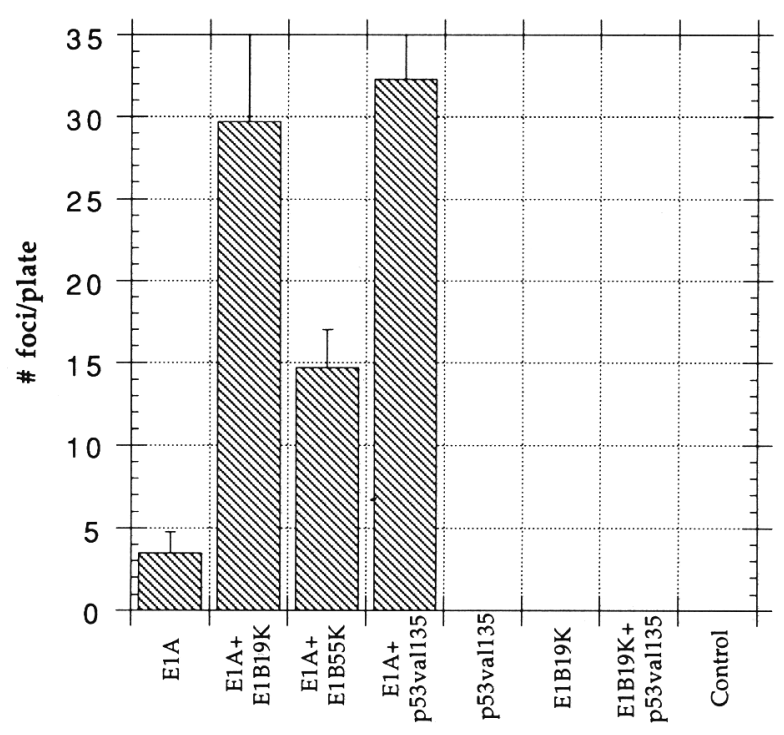

Figure 1. Cooperation between $\mathrm{E} 1 \mathrm{~A}$ and murine mutant $\mathrm{p} 53$ in primary BRK cells. Primary BRK cells were transfected by standard procedure with the following DNAs-E1A, pCMVE1A (White et al. 1991); E1B19K, pCMV19K; E1B55K, pCMV55K (White and Cipriani 1990); p53val135, pLTRcGval135 (Michalovitz et al. 1990)-and were maintained at $37.5^{\circ} \mathrm{C}$. Focus formation was determined at 30 days post-transfection. 
pressed murine mutant $\mathrm{p} 53$ and E1A at comparable levels as determined by Western blotting of cell extracts with E1A and murine p53-specific monoclonal antibodies (Fig. 2,top). E1A protein levels in E1A + p53(val135) transformants were similar to those found in E1A+E1Btransformed cell lines (Fig. 2,top).

\section{Wild-type p53 induces apoptosis in transformed cells}

The viability of E1A + p53|val135| transformants was examined when $\mathrm{p} 53$ was returned to the wild-type conformation. All lines grew efficiently (Fig. 2, bottom) and morphologically resembled E1A + E1B-transformed lines
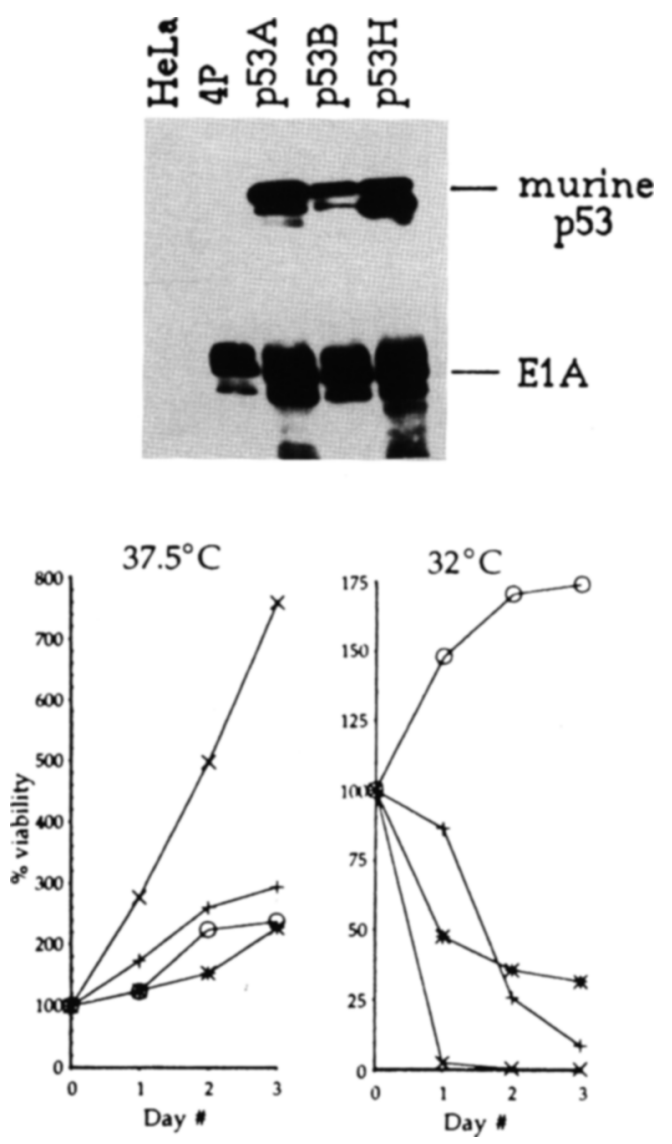

Figure 2. Induction of cell death in transformed BRK lines when p53 is in the wild-type conformation. (Top) Levels of murine $\mathrm{p} 53$ and $\mathrm{E} 1 \mathrm{~A}$ in transformed $\mathrm{BRK}$ lines. Three independent $\mathrm{E} 1 \mathrm{~A}+\mathrm{p} 53 \mid$ val135| lines, p53A, p53B, p53H, were derived from foci of transfections described in Fig. 1. Equal amounts of cell extract for each line were analyzed for E1A and murine p53 levels, with monoclonal antibodies $M 73$ and pAb248, respectively, by Western blotting. The 4P (White and Cipriani 1990) line is a previously characterized E1A + E1B-transformed BRK line as a reference for ElA levels. (Bottom) Viability of $\mathrm{E} 1 \mathrm{~A}+\mathrm{p} 53$ (vall35) transformants at permissive temperature $\left(32^{\circ} \mathrm{C}\right)$, where $\mathrm{p} 53$ is predominantly in the wild-type conformation, and at the restrictive temperature $\left(37.5^{\circ} \mathrm{C}\right)$ where p53 is predominantly mutant. Viability as determined by Trypan blue exclusion is expressed as the percentage of the original viability at the time of shift to $32^{\circ} \mathrm{C} .(\times) \mathrm{p} 53 \mathrm{~A}_{i}\left(^{*}\right) \mathrm{p} 53 \mathrm{~B}_{i}(+) \mathrm{p} 53 \mathrm{H}_{i}(\mathrm{O}) 4 \mathrm{P}$. at the restrictive temperature (data not shown). Pronounced loss of viability occurred within $24 \mathrm{hr}$ in all three independent E1A + p53(val135) lines after a shift from restrictive to permissive temperatures (Fig. 2, bottom). Viability loss continued for $72 \mathrm{hr}$ (Fig. 2, bottom) and progressed nearly to completion if the lines were maintained at the permissive temperature for 2 weeks. Rare survivors arose as colonies at $32^{\circ} \mathrm{C}$ with a frequency of $\sim 1$ in $10^{6}$ cells (data not shown). For comparison, an $\mathrm{E} 1 \mathrm{~A}+\mathrm{E} 1 \mathrm{~B}$-transformed BRK line 4P, which does not contain a temperature-sensitive mutant p53 protein /White and Cipriani 1990), not only maintained viability but continued to grow at $32^{\circ} \mathrm{C}$ (Fig. 2, bottom). Massive cytopathic effect was coincident with viability loss in the $\mathrm{E} 1 \mathrm{~A}+\mathrm{p} 53($ vall35) transformants but not in the E1A + E1B control cell line 4P (see below).

$\mathrm{E} 1 \mathrm{~A}+\mathrm{p} 53$ (val135) transformants were examined for indications of apoptosis, DNA fragmentation, and chromatin condensation, accompanying viability loss at the permissive temperature. When maintained at the restrictive temperature where viability was high, none of the lines demonstrated DNA fragmentation. By $24 \mathrm{hr}$ after shift to the permissive temperature, and coincident with viability loss, chromosomal DNA was degraded into nucleosome-size fragments in all three E1A + p53(vall35) lines (Fig. 3). DNA fragmentation persisted for $72 \mathrm{hr}$ (Fig. 3). No DNA fragmentation was observed in the control cell line $4 \mathrm{P}$ at any time of incubation at $32^{\circ} \mathrm{C}$ (Fig. 3). Condensation of chromatin and DNA into large aggregates, another indicator of cell death by apoptosis, was also observed in $\mathrm{E} 1 \mathrm{~A}+\mathrm{p} 53$ (vall35) transformants at $32^{\circ} \mathrm{C}$ (data not shown). The fastest growing E1 A + p53(val135)transformed line, p53A, displayed the most extreme induction of cell death and was utilized to test the ability of the E1B $19 \mathrm{~K}$ protein to inhibit apoptosis by wild-type p53.

E1B $19 \mathrm{~K}$ protein blocks induction of apoptosis by wild-type $p 53$

p53A was transfected with a neomycin-resistance marker alone or, additionally, with the E1B $19 \mathrm{~K}$ plasmid expression vector $\mathrm{pCMV19K}$. Drug-resistant clones were screened for 19K expression by Western blotting with a monoclonal antibody directed against the E1B $19 \mathrm{~K}$ protein. Two independent $\mathrm{p} 53 \mathrm{~A}$ clones were identified that expressed the $19 \mathrm{~K}$ protein (p53A19K1, p53A19K2) in parallel with two independent control p53A derivatives that were only neomycin resistant (p53An1, p53An2) (Fig. 4 ,top). All four lines displayed similar growth rates (Fig. 4,bottom) and morphology (data not shown) when maintained at the restrictive temperature. Therefore, E1B 19K expression did not enhance the transformed cell phenotype or growth properties in a conspicuous way. The ability of the E1B 19K protein to inhibit apoptosis upon conformational shift of p53 from the mutant to the wildtype form was examined.

The p53A derivatives that were merely drug resistant rapidly lost viability when shifted to $32^{\circ} \mathrm{C}$ as did the original parental line p53A (Fig. 4, bottom). The p53A 


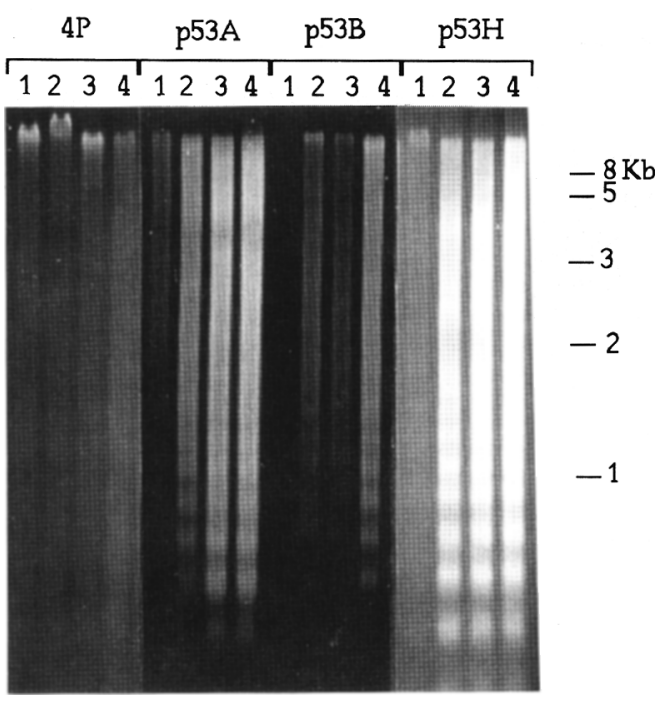

Figure 3. Induction of DNA fragmentation by wild-type p53. DNA integrity was determined in the three independent $\mathrm{E} 1 \mathrm{~A}+\mathrm{p} 53$ (vall35)- transformed BRK lines, p53A, p53B, p53H, and the $\mathrm{E} 1 \mathrm{~A}+\mathrm{E} 1 \mathrm{~B}$ control line, $4 \mathrm{P}$, at the restrictive temperature $\left(37.5^{\circ} \mathrm{C}\right.$, lane 1$)$ and following shift to the permissive temperature $\left(32^{\circ} \mathrm{C}\right.$ ) for 24 (lane 2), 48 (lane 3), and 72 (lane 4 ) hr. Low-molecular-weight DNA was isolated by a modified Hirt assay (Hirt 1967) from nonadherant (apoptotic) cells. Cell lines were equalized with respect to the viable cell number at the time of the shift to $32^{\circ} \mathrm{C}$. The presence of degraded DNA was determined by electrophoresis of Hirt DNA samples on $1 \%$ agarose gels, and the DNA was visualized with ethidium bromide. Presence of low-molecular weight DNA in a nucleosome ladder pattern is indicative of apoptosis.

derivatives that expressed the E1B $19 \mathrm{~K}$ protein, however, maintained viability after shift to $32^{\circ} \mathrm{C}$ (Fig. 4, bottom). Expression of the E1B $19 \mathrm{~K}$ protein also prevented the induction of pronounced cytopathic effect that accompanied viability loss in ElA + p53(vall35) transformants (Fig. 5). Interestingly, the 19K-expressing lines did not grow efficiently at $32^{\circ} \mathrm{C}$, suggesting that $19 \mathrm{~K}$ expression was sufficient to block apoptosis but insufficient to completely overcome induction of growth arrest by wild-type p53 in these lines. After 3 days the 19K-expressing lines did appear to grow at a slow rate. Any potential effects on the cell cycle in these lines is currently under investigation. The growth-suppressive effect of p53 in these 19Kexpressing transformants was reversible, with cell proliferation being restored upon return to the restrictive temperature (data not shown).

The integrity of chromosomal DNA was monitored as an indicator of death by apoptosis in the p53A derivatives at $37.5^{\circ} \mathrm{C}$ and after shift to $32^{\circ} \mathrm{C}$. Low-molecularweight (degraded) DNA was selectively extracted from all four lines with increasing time at the permissive temperature. Although no DNA fragmentation was apparent at the high temperature, pronounced DNA fragmentation into a nucleosome "ladder" pattern was induced in the $19 \mathrm{~K}$-minus lines at $32^{\circ} \mathrm{C}$ (Fig. 6). Although low-molecular-weight DNA was extracted from the equivalent numbers of cells in all four lines, little DNA was present in the Hirt extracts of the 19K-expressing lines because
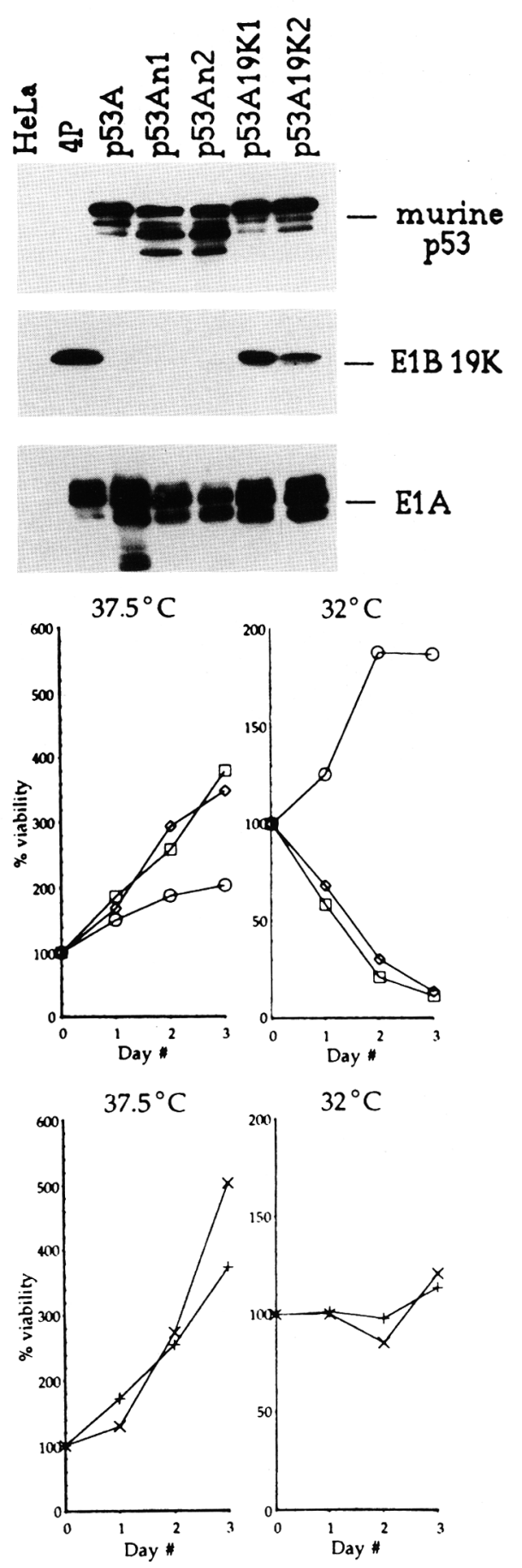

Figure 4. The E1B $19 \mathrm{~K}$ protein blocks cell death induced by wild-type p53. (Top) Expression of E1A, murine p53, and the E1B $19 \mathrm{~K}$ protein in the $\mathrm{E} 1 \mathrm{~A}+\mathrm{p} 53$ (val 135) transformant $\mathrm{p} 53 \mathrm{~A}$ derivatives by Western blotting with murine p53, E1B $19 \mathrm{~K}$, and E1Aspecific monoclonal antibodies. (Bottom) Viable cell number, as described in Fig. 2, was determined for four independent p53A derivatives that did (p53A19K1, p53A19K2) or did not (p53An1, p53An2) express the E1B 19K protein. (ㅁ) p53An1; $(\diamond)$ p53An2; (O) $4 \mathrm{P} ;(\times)$ p53A19K1; $1+\mid$ p53A19K2. 


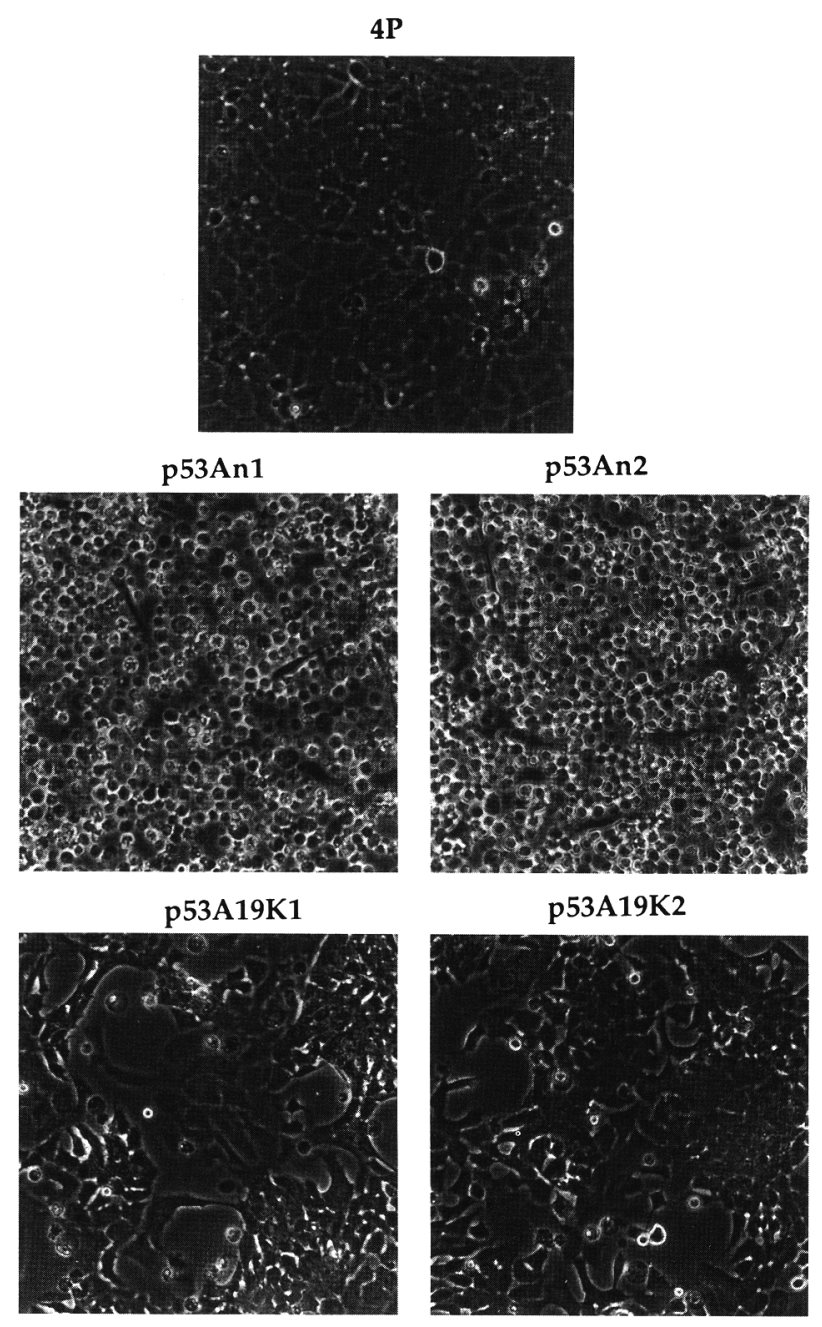

Figure 5. Induction of cytopathic effect by wild-type p53 is blocked by E1B 19K expression. The 19K-expressing and -nonexpressing p53- derived cell lines described in Fig. 4 were photographed $48 \mathrm{hr}$ after the shift from restrictive to permissive temperatures. Magnification, $25 \times$.

the DNA was intact and partitioned with the high-molecular-weight DNA fraction (Fig. 6). Expression of the ElB $19 \mathrm{~K}$ protein completely suppressed the induction of DNA fragmentation that occurred with conformational shift of p53 from the mutant to the wild-type form. Thus, the E1B $19 \mathrm{~K}$ protein was capable of completely inhibiting induction of apoptosis resulting from the presence of wild-type p53 in transformed BRK cells.

\section{Discussion}

Apoptosis requires E1A expression in the presence of wild-type p53

In previous studies it became apparent that expression of ElA was detrimental to cell viability unless the protec-

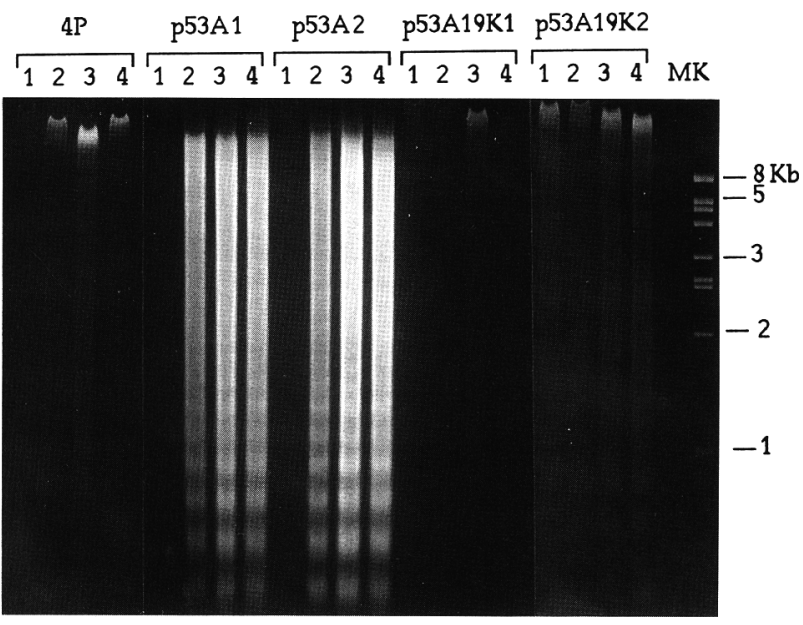

Figure 6. The E1B 19K protein blocks induction of DNA fragmentation by wild-type p53. DNA fragmentation was monitored with a modified Hirt assay (Hirt 1967) in parallel with the viability assay in Fig. 4. (Lane 1) Cells at $37.5^{\circ} \mathrm{C}$ at the time of the shift to $32^{\circ} \mathrm{C}$; (lanes $2-4$ ) incubation for 24 (lane 2), 48 (lane 3 ), and 72 (lane 4 ) hr at $32^{\circ} \mathrm{C}$. (MK) Ad5dl309 DNA digested with HindIII as molecular weight markers.

tive function of ElB was provided (White and Stillman 1987, White et al. 1991). The p53 tumor suppressor gene product can also overcome apoptosis in primary cells when in the mutant conformation and must be maintained, as mutant or E1A transformants will undergo apoptosis. Furthermore, the E1B 55K protein that sequesters wild-type p53 into an inactive complex creating a p53 null state will rescue apoptosis in E1A-expressing cells (Rao et al. 1992). Thus, ElA does not induce apoptosis in the absence of wild-type $\mathrm{p} 53$. This provides evidence that p53 is directing apoptosis in response to E1A expression during transformation of primary rodent cells (Fig. 7, top). Because p53 is ubiquitously expressed at low levels in normal cells that are not undergoing apoptosis
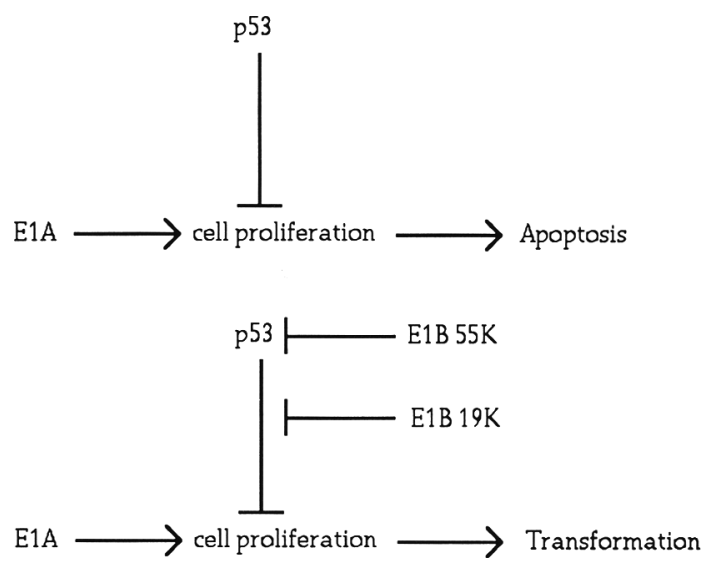

Figure 7. Model for regulation of cell proliferation and apoptosis by E1A and E1B gene products (for explanation, see discussion). 
(Levine et al. 1991), induction of apoptosis must reflect a change in status of the cell by ElA and modification of p53 activity.

Induction of proliferation by E1A may be incompatible with induction of growth arrest by $p 53$

Mapping studies indicate that induction of apoptosis is a function of the ElA amino terminus that encompasses conserved region 1 (White et al. 1991). Specifically, deletion of amino acids 22-107 (PSdl mutation) in the amino-terminal region of E1A will prevent induction of apoptosis in adenovirus E1B 19K mutant virus-infected cells (White et al. 1991). Removal of sequences elsewhere in E1A, such as the trans-activation domain in the 13S unique region (conserved region 3), or the retinoblastoma protein- binding region in conserved region 2, does not alleviate apoptosis (White et al. 1991). The amino terminus of E1A is required for induction of cellular DNA synthesis, enhancer repression, and transformation (for review, see Shenk and Flint 1991), but which of these activities is related to apoptosis remains to be determined. The PD $d l$ mutation in ElA, however, can be distinguished from the other E1A mutants examined because it produces a mutant protein that is completely defective for induction of cellular DNA synthesis (Moran and Zerler 1988; Stein et al. 1991). The ability of E1A to release restrictions on growth control and induce S-phase, therefore, correlates with induction of apoptosis.

These genetic studies have raised the possibility that induction of cell proliferation by E1A is incompatible with growth suppression by p53 (Fig. 7, top). The consequence of E1A overcoming p53 cytostasis is apoptosis. In that way the cell may regulate inappropriate, abnormal, or untimely DNA synthesis by eliminating cells through p53-dependent apoptosis. The process could be instigated by viral infection or by the accumulation of mutations that lead to the progressive loss of growth control in emerging transformed cells.

Alternatively, the indirect consequences of loss of growth control may cause p53-dependent apoptosis. Abnormal or deregulated DNA synthesis produced by E1A could create DNA damage sufficient to provoke a growth arrest and cell suicide response by p53. p53 functions as a cell cycle control checkpoint in response to DNA damage. p53 protein accumulates in response to DNA damage (Maltzman and Czyzyk 1984), producing cell cycle arrest at $\mathrm{G}_{1} / \mathrm{S}$ and repair (Kastan et al. 1991,1992; Kuerbitz et al. 1992) and, perhaps, apoptosis when DNA damage is so severe as to be irreparable. With loss of p53 function, the $G_{1} / S$ checkpoint is bypassed, allowing replication of damaged DNA to take place (Kastan et al. 1991,1992; Kuerbitz et al. 1992) and transmission of genetic alterations including gene amplification /Livingstone et al. 1992; Yin et al. 1992). E1A expression has been linked to induction of DNA damage (Braithwaite et al. 1983; Caporossi and Bacchetti 1990), and p53 accumulation has been observed in response to ElA expression (Lowe and Ruley, this issue; E. White and L. Rao, in prep.). Thus, p53 responds to E1A expression in a way that mimics its response to DNA damage.

\section{The role of the $E 1 B 19 \mathrm{~K}$ protein in preventing} apoptosis by $p 53$

The experiments presented here demonstrate that the E1B gene encodes redundant functions, represented by the $55 \mathrm{~K}$ and $19 \mathrm{~K}$ proteins, for bypassing the activity of p53. The E1B 55K protein directly inhibits p53 function (Fig. 7, bottom) because physical association between $55 \mathrm{~K}$ and p53 is usually required for blocking p53 activity in transformation and as a transcription factor /Yew and Berk 1992). However, in productively infected human cells the E1B $55 \mathrm{~K}$ protein is complexed with the $25 \mathrm{~K}$ protein from the E4 region of adenovirus, which may interfere with p53 association (Sarnow et al. 1984). This may necessitate the need for an auxiliary mechanism encoded by the E1B $19 \mathrm{~K}$ protein for disabling the function of $\mathrm{p} 53$.

The E1A and E1B $19 \mathrm{~K}$ proteins together will overcome growth arrest by $\mathrm{p} 53$ as their expression will transform cells (White and Cipriani 1990; Rao et al 1992; White et al. 1992). Presumably under these circumstances their expression is sufficient to overcome growth arrest by the endogenous wild-type p53 present in the primary BRK cells (Fig. 7, bottom). The E1A + p53(val135) transformants express much larger amounts of wild-type p53 at the permissive temperature than in the primary cells. The levels of E1B 19K expression in these lines may not be enough to completely block the growth inhibitory effects of wild-type p53, which may account for the reduced growth capacity of these cells at the permissive temperature. Ongoing experiments will distinguish whether E1B 19K protein function is restricted to inhibition of apoptosis by p53 or can be extended to other aspects of $\mathrm{p} 53$ function.

The E1B $19 \mathrm{~K}$ protein may block p53 function by a direct or indirect mechanism (Fig. 7, bottom). Although no physical interaction between the E1B $19 \mathrm{~K}$ and p53 proteins has been reported, the results presented here indicate that this possibility should be placed under closer scrutiny. Interference in p53 function, however, need not be direct. Changes in the localization and phosphorylation state of $\mathrm{p} 53$ are known to affect p53 function and may be modified by the E1B $19 \mathrm{~K}$ protein. Examination of the p53 protein in cell lines that express the E1B $19 \mathrm{~K}$ protein in comparison to those that do not, may help to address this issue. It is also possible that the E1B $19 \mathrm{~K}$ protein acts far downstream of p53 in the apoptotic pathway. The E1B $19 \mathrm{~K}$ protein resides in the nuclear envelope where it can potentially modify chromatin structure to prevent the endonucleolytic cleavage of DNA that occurs during apoptosis (White et al. 1984a). In that way p53-dependent apoptosis could be bypassed indirectly (Fig. 7, bottom).

How wild-type p53 causes growth arrest and apoptosis is not known. The wild-type p53 protein specifically binds to DNA at a defined consensus sequence (El-Deiry et al. 1992) and can act as a transcriptional activator in a 
sequence-specific fashion (Farmer et al. 1992; Zambetti et al. 1992). p53 can also repress transcription, although no specific sequence requirement has been identified (Ginsberg et al. 1991a). The E1B 55K protein and the E6 protein of human papillomavirus can both alter the transcriptional activity of p53 (Lechner et al. 1992; Yew and Berk 1992). This suggests that modulation of cellular gene transcription by 53 may be important for its function as a tumor suppressor. Whether transcriptional activation or repression by p 53 are affected by the E1B $19 \mathrm{~K}$ protein is currently under investigation.

p53 may also play a direct role in cellular DNA replication. Translocation of $\mathrm{p} 53$ from the cytoplasm to the nucleus occurs at the $G_{1} / S$ boundary, and expression of wild-type p53 can cause growth arrest at $\mathrm{G}_{1} / \mathrm{S}$ (Baker et al. 1990; Diller et al. 1990; Mercer et al. 1990; Martinez et al. 1991). Wild-type but not mutant p53 has been shown to bind to sequences within the SV40 origin of replication, raising the possibility that p53 may prevent DNA synthesis by a direct mechanism (Bargonetti et al. 1991). It will be interesting to examine whether these activities of p53 are related to induction of apoptosis and are also affected by the E1B $19 \mathrm{~K}$ protein.

The E1B 19K protein not only has the ability to block apoptosis induced by wild-type p53 but also by TNF- $\alpha$ and Fas antigen. If inhibition of p53 function is central to the ability of the E1B $19 \mathrm{~K}$ protein to block apoptosis, TNF- $\alpha$ and Fas antigen may utilize the p53 pathway to induce apoptosis. This would explain the ability of the E1B 19K protein to inhibit apoptosis by such apparently diverse stimuli and would suggest a role for p53 in negative selection and antiviral immune surveillance.

The discovery that adenovirus has evolved mechanisms for both inducing proliferation and blocking apoptosis is generally significant and may represent the basic requirements for the development of cancer. Amplification of c-myc proto-oncogene expression, which has growth-deregulating properties analogous to $\mathrm{ElA}$, similarly produces apoptosis (Bissonnette et al. 1992; Evan et al. 1992; Fanidi et al. 1992). Therefore, apoptosis may be a response to aberrant proliferation. p53 mutations are the most common genetic alterations found in human cancer (Levine et al. 1991). A p53-mediated cell suicide response may be an important cellular defense against cancer and may necessitate the evolution by DNA tumor viruses of multiple mechanisms for disabling the process.

\section{Materials and methods}

\section{Plasmids and primary cell transformation assays}

Cytomegalovirus (CMV) promoter constructs were utilized to express the E1A (pCMVE1A) (White et al. 1991), E1B 19K (pCMV19K), and 55K (pCMV55K) proteins (White and Cipriani 1990 ) in transformation assays. The plasmid pLTRcGval135 (Michalovitz et al. 1990) was utilized to express murine mutant p53. The p53(val135) protein is temperature sensitive and is predominantly in the mutant conformation at $37.5^{\circ} \mathrm{C}$ and predominantly in the wild-type conformation at $32^{\circ} \mathrm{C}$ /Michalovitz et al. 1990; Gannon and Lane 1991; Martinez et al. 1991). Trans- formation assays and continuous propagation of transformants containing the p53/vall35) protein were carried out at $37.5^{\circ} \mathrm{C}$.

Primary Fisher BRK cells were prepared as described previously (White et al. 1991). Plasmids were introduced by electroporation, and cells were maintained in Dulbecco's modified Eagle medium with $5 \%$ fetal bovine serum. At 30 days posttrans. fection, plates were stained with Giemsa and foci were tabulated. Focus diameter of $5 \mathrm{~mm}$ or greater was used as a criterion for focus formation. A minimum of eight plates from two independent experiments for each plasmid combination was analyzed. Independent transformed foci were cloned at $\sim 6$ weeks after transfection and maintained as continuous cell lines. Three E1A + p53(vall35) transformants, p53A, p53B, and $\mathrm{p} 53 \mathrm{H}$, were evaluated further for E1 $\mathrm{A}$ and murine p53 levels and induction of apoptosis. The transformed BRK cell line, p53A, that derived from transfection of pCMVE1A and pLTRcGval135 plasmids was transfected with the pCMV19K plasmid and a neomycin-resistance marker by electroporation. Independent cell lines were selected with G418 and characterized for $19 \mathrm{~K}$ expression by Western blotting with 19K-specific antibodies. Two lines, p53A19K1 and p53A19K2, were evaluated further for induction of apoptosis. Control cell lines p53An1 and p53An2, derived from p53A containing only the neomycin-resistance marker, were constructed in parallel.

\section{Antibodies and Western blotting}

Monoclonal antibodies directed against murine p53 (pAb248 and $\mathrm{pAb} 2 \mathrm{C} 2$ / were generously provided by Dr. Arnold J. Levine (Princeton University, NJ). The E1A-specific monoclonal antibody M73 was generously provided by Dr. Ed Harlow (Massachusetts General Hospital, Charlestown, MA|. E1B 19K-specific antibodies have been described previously (White et al. 1984a). Cell extracts for Western analysis were prepared from subconfluent cultures, and $20 \mu \mathrm{g}$ of protein from each cell line was analyzed by polyacrylamide gel electrophoresis and semidry blotting onto nitrocellulose membranes by standard procedures. Following antibody incubations, immune complexes were detected by enhanced chemiluminescence (ECL) according to the manufacturer's specifications (Amersham). The E1A+E1Btransformed BRK cell line 4P (White and Cipriani 1990) was utilized as a control for E1A and E1B expression.

\section{Viability and DNA fragmentation analysis}

Transformed BRK cell lines were plated at a density of $1.5 \times 10^{5}$ cells per $6-\mathrm{cm}$ plate at $37.5^{\circ} \mathrm{C}$. Forty hours postplating, when the cells were completely attached to the substrate, the cells were trypsinized and the viable cell number per plate was determined by Trypan blue exclusion. The remaining plates were shifted to $32^{\circ} \mathrm{C}$, and the viable cell number was determined after incubation for 24,48 , and $72 \mathrm{hr}$. For DNA fragmentation assays, apoptotic cells were harvested from the culture medium of transformed BRK cell lines by low-speed centrifugation. The apoptosis cells were then subjected to a modified Hirt procedure, which permits the selective isolation of low-molecular-weight degraded DNA from high-molecular-weight intact chromosomal DNA (Hirt 1967; White et al. 1984b). Hirt supernatant fractions from BRK lines were equalized with respect to the original cell number at the time of the shift to $32^{\circ} \mathrm{C}$. Hirt DNA was analyzed by electrophoresis in a $1 \%$ agarose gel and visualized by ethidium bromide staining.

\section{Acknowledgments}

We thank A.J. Levine and E. Harlow for providing monoclonal 
antibodies against murine p53 and E1A, and H.E. Ruley and S. Lowe for communicating their results before publication. This work was supported by a grant from the National Cancer Institute CA53370 (to E.W.) and the New Jersey Commission on Science and Technology.

The publication costs of this article were defrayed in part by payment of page charges. This article must therefore be hereby marked "advertisement" in accordance with 18 USC section 1734 solely to indicate this fact.

\section{References}

Alnemri, E.S., T.F. Fernandes, S. Haldar, C.M. Croce, and G. Litwack. 1992. Involvement of BCL-2 in glucocorticoid-induced apoptosis of human pre-B-leukemias. Cancer Res. 52: 491-495.

Baker, S.J., S. Markowitz, E.R. Fearon, J.K.V. Willson, and B. Vogelstein. 1990. Suppression of human colorectal carcinoma cell growth by wild-type p53. Science 249: 912-915.

Bargonetti, J., P.N. Friedman, S. Kern, B. Vogelstein, and C. Prives. 1991. Wild-type but not mutant p53 immunopurified proteins bind to sequences adjacent to the SV40 origin of replication. Cell 65: 1083-1091.

Bissonnette, R.P., F. Echeverri, A. Mahboubi and D. Green. 1992. Apoptotic cell death induced by c-myc is inhibited by bcl-2. Nature 359: 552-554.

Braithwaite, A.W., B.F. Cheetam, P. Li, C.R. Parish, L.K. Waldron-Stevens, and A.J.D. Bellett. 1983. Adenovirus-induced alterations in the cell growth cycle: A requirement for the expression of E1A but not of E1B. J. Virol. 45: 192-199.

Caporossi, D. and S. Bacchetti. 1990. Definition of adenovirus type 5 functions involved in the induction of chromosomal aberrations in human cells. J. Gen. Virol. 71: 801-808.

Diller, L., J. Kassel, C.E. Nelson, M.A. Gryka, G. Litwak, M. Geghardt, and B. Bressac. 1990. p53 functions as a cell cycle control protein in osteosarcomas. Mol. Cell. Biol. 10: 57725781.

El-Deiry, W. S., S.E. Kern, J.A. Pietenpol, K.W. Kinzler, and B. Vogelstein. 1992. Definition of a consensus binding site for p53. Nature Genet. 1: 45-49.

Evan, G.I., A.H. Wyllie, C.S. Gilbert, T.D. Littlewood, H. Land, M. Brooks, C.M. Waters, L.Z. Penn, and D.C. Hancock. 1992. Induction of apoptosis in fibroblasts by c-myc protein. Cell 69: 119-128.

Fanidi, A., E.A. Harrington, and G. Evan. 1992. Cooperative interaction between c-myc and $b c l-2$ proto-oncogenes. $\mathrm{Na}$ ture 359: 554-556.

Farmer, G., J. Bargonetti, H. Zhu, P. Friedman, R. Prywes, and C. Prives. 1992. Wild-type p53 activates transcription in vitro. Nature 358: 83-86.

Finlay, C.A., P.W. Hinds and A.J. Levine. 1989. The p53 protooncogene can act as a suppressor of transformation. Cell 57: 1083-1093.

Gannon, J.V. and D.P. Lane. 1991. Protein synthesis required to anchor a mutant $\mathrm{p} 53$ protein which is temperature-sensitive for nuclear transport. Nature 349: 802-806.

Ginsberg, D., F. Mechta, M. Yaniv, and M. Oren. 1991a. Wildtype p53 can down-modulate the activity of various promoters. Proc. NatI. Acad. Sci. 88: 9979-9983.

Ginsberg, D., D. Michael-Michalovitz, D. Ginsberg, and M. Oren. 1991b. Induction of growth arrest by a temperaturesensitive p53 mutant is correlated with increased nuclear localization and decreased stability of the protein. Mol. Cell. Biol. 11: 582-585.

Gooding, L.R., L. Aquino, P.J. Duerlsen-Hughes, D. Day, T.M.
Horton, S. Yei, and W.S.M. Wold. 1991. The E1B-19K protein of group $\mathrm{C}$ adenoviruses prevents cytolysis by tumor necrosis factor of human cells but not mouse cells. J. Virol 65: 3083-3094.

Hashimoto, S., A. Ishii, and S. Yonehara. 1991. The E1B oncogene of adenovirus confers cellular resistance to cytotoxicity of tumor necrosis factor and monoclonal anti-Fas antibody. Int. Immunol 3: 343-351.

Hirt, B. 1967. Selective extraction of polyoma DNA from infected mouse cultures. J. Mol. Biol. 26: 365-369.

Hockenbery, D., G. NuA4"ez, C. Milliman, R.D. Schreiber, and S. Korsmeyer. 1990. Bcl-2 is an inner mitochondrial membrane protein that blocks programmed cell death. Nature 348: 334-336.

Itoh, N., S. Yonehara, A. Ishii, M. Yoenhara, S. Mizushima, M. Sameshima, A. Hase, Y. Seto, and S. Nagata. 1991. The polypeptides encoded by the cDNA for human cell surface antigen Fas can mediate apoptosis. Cell 66: 233-243.

Kaczmarek, L., B. Ferguson, M. Rosenberg, and R. Baserga. 1986. Induction of cellular DNA synthesis by purified adenovirus E1A proteins. Virology 152: 1-10.

Kastan, M. B., O. Onyekwere, D. Sidransky, B. Vogelstein, and R.W. Craig. 1991. Participation of p53 protein in the cellular response to DNA damage. Cancer Res. 51: 6304-6311.

Kastan, M.B., Q. Zhan, W.S. El-Deiry, F. Carrier, T. Jacks, W.V. Walsh, B.S. Plunkett, B. Vogelstein, and A.J. Fornace. 1992. A mammalian cell cycle checkpoint pathway utilizing p53 and GADD45 is defective in ataxia-telangiectasia. Cell 13: 587597.

Kuerbitz, S.J., B.S. Plunkett, W.V. Walsh, and M.B. Kastan. 1992. Wild-type p53 is a cell cycle checkpoint determinant following irradiation. Proc. Nat1. Acad. Sci. 89: 7491-7495.

Laster, S.M., J.G. Good, and L.R. Gooding. 1988. Tumor necrosis factor can induce both apoptic and nedrotic forms of cell lysis. J. Immunol. 141: 2629-2634.

Lechner, M.S., D.H. Mack, A.B. Finicle, T. Crook, K.H. Vousden, and L.A. Laimins. 1992. Human papillomavirus E6 proteins bind p53 in vivo and abrogate p53-mediated repression of transcription. EMBO $J$. 11: 3045-3052.

Levine, A., J. Momand, and C.A. Finlay. 1991. The p53 tumour suppressor gene. Nature 351: 453-456.

Livingstone, L.R., A. White, J. Sprouse, E. Livanos, T. Jacks, and T. D. Tisty. 1992. Altered cell cycle arrest and gene amplification potential accompany loss of wild-type p53. Cell 70: 923-935.

Maltzman, W. and L. Czyzyk. 1984. UV irradiation stimulates levels of p53 cellular tumor antigen in nontransformed mouse cells. Mol. Cell. Biol. 4: 1689-1694.

Martinez, J., I. Georgoff, J. Martinez, and A.J. Levine. 1991. Cellular localization and cell cycle regulation by a temperaturesensitive p53 protein. Genes \& Dev. 5: 151-159.

McDonnell, T.J. and S.J. Korsmeyer. 1991. Murine model of the $t(14 ; 18)$ progresses from lymphoid hyperplasia to high grade malignant lymphoma. Nature 349: 254-275.

Mercer, W.E., M.T. Shields, M. Amin, G.J. Suave, E. Appella, J.W. Romano, and S. J. Ullrich. 1990. Negative growth regulation in a gliobastoma tumor cell line that conditionally expresses human wild-type p53. Proc. Natl. Acad. Sci. 87: 6166-6170.

Michalovitz, D., O. Halevy, and M. Oren. 1990. Conditional inhibition of transformation and of cell proliferation by a temperature-sensitive mutant of p53. Cell 62: 671-681.

Moran, E. and B. Zerler. 1988. Interactions between cell growthregulating domains in the products of the adenovirus E1A oncogene. Mol. Cell. Biol. 8: 1756-1764.

Nuñez, G., L. London, D. Hockenbery, J.P. McKearn, and S.J. 
Korsmeyer. 1990. Deregulated Bcl-2 gene expression selectively prolongs survival of growth factor-deprived hematopoietic cell lines. I. Immunol. 144: 3602-3610.

Nuñez, G., D. Hockenbery, T.J. McDonnell, C.M. Sorensen, and S.J. Korsmeyer. 1991. Bcl-2 maintains B cell memory. Nature 353: $71-73$.

Pilder, S., J. Logan, and T. Shenk. 1984. Deletion of the gene encoding the adenovirus 5 early region $1 \mathrm{~B}-21,000$-molecular weight polypeptide leads to degradation of viral and cellular DNA. I. Virol. 52: 664-671.

Pines, J. and T. Hunter. 1990. Human cyclin A is adenovirus E1A-associated protein $\mathrm{p} 60$ and behaves differently from cyclin B. Nature 346: 760-763.

Rao, L., M. Debbas, P. Sabbatini, D. Hockenbery, S. Korsmeyer, and E. White. 1992. The adenovirus E1A proteins induce apoptosis which is inhibited by the E1B 19K and Bcl-2 proteins. Proc. Natl. Acad. Sci. 89: 7742-7746.

Sarnow, P., Y.S. Ho, J. Williams, and A.J. Levine. 1982. Adenovirus E1b-58 kd tumor antigen and SV40 large tumor antigen are physically associated with the same $54 \mathrm{kd}$ cellular protein in transformed cells. Cell 28: 387-394.

Sarnow, P., P. Hearing, C.W. Anderson, D.N. Halbert, T. Shenk, and A. J. Levine. 1984. Adenovirus early region 1 B 58,000dalton tumor antigen is physically associated with an early region 25,000 -dalton protein in productively infected cells. $J$. Virol. 49: 692-700.

Sentman, C.L., J.R. Shutter, D. Hockenbery, O. Kanagawa, and S.J. Korsmeyer. 1991. bcl-2 inhibits multiple forms of apoptosis but not negative selection in thymocytes. Cell 67: 879888.

Shaw, P., R. Bovey, S. Tardy, R. Sahli, B. Sordat, and J. Costa. 1992. Induction of apoptosis by wild-type p53 in a human colon tumor derived cell line. Proc. Nat1. Acad. Sci. 89: 4495-4499.

Shenk, T. and J. Flint. 1991. Transcriptional and transforming activities of the adenovirus ElA proteins. Adv. Cancer Res. 57: 47--85.

Stabel, S., P. Argos, and L. Philipson. 1985. The release of growth arrest by microinjection of adenovirus E1A DNA. EMBO J. 4: 2329-2336.

Stein, R.W., M. Corrigan, P. Yaciuk, J. Whelan, and E. Moran. 1991. Analysis of ElA-mediated growth regulation functions: Binding of the 300-kilodalton cellular product correlates with elA repression function and DNA synthesis-inducing activity. J. Virol. 64: 4421-4427.

Strasser, A., A.W. Harris, and S. Cory. 1991. bcl-2 transgene inhibits $\mathrm{T}$ cell death and perturbs thymic self-censorship. Cell 67: 889-899.

Subramanian, T., M. Kuppuswamy, J. Gysbers, S. Mak, and G. Chinnadurai. 1984. 19-kDa tumor antigen coded by early region Elb of adenovirus 2 is required for efficient synthesis and for protection of viral DNA. J. Biol. Chem. 259: 1177711783.

Takemori, N., C. Cladaras, B. Bhat, A.J. Conley, and W.S.M. Wold. 1984. cyt gene of adenovirus 2 and 5 is an oncogene for transforming function in early region $\mathrm{E} 1 \mathrm{~B}$ and encodes the E1B 19,000-molecular-weight polypeptide. I. Virol. 52: 793805.

Vaux, D.L., S. Cory, and T.M. Adams. 1988. Bcl-2 promotes the survival of haemopoietic cells and cooperates with c-myc to immortalize pre-b cells. Nature 335: 440-442.

Vogelstein, B. 1990. A deadly inheritance. Nature 348: 681-682.

White, E. and R. Cipriani. 1990. Role of adenovirus E1B proteins in transformation: Altered organization of intermediate filaments in transformed cells that express the 19-kilodalton protein. Mol. Cell. Biol. 10: 120-130.
White, E. and B. Stillman 1987. Expression of the adenovirus E1B mutant phenotypes is dependent on the host cell and on synthesis of E1A proteins. J. Virol. 61: 426-435.

White, E., S.H. Blose, and B. Stillman. 1984a. Nuclear envelope localization of an adenovirus tumor antigen amintains the integrity of cellular DNA. Mol. Cell. Biol. 4: 2865-2875.

White, E., T. Grodzicker, and B.W. Stillman. 1984b. Mutations in the gene encoding the adenovirus E1B 19K tumor antigen cause degradation of chromosomal DNA. I. Virol. 52: 410419.

White, E., R. Cipriani, P. Sabbatini, and A. Denton. 1991. Adenovirus E1B 19-kilodalton protein overcomes the cytotoxicity of E1A proteins. I. Virol. 65: 2968-2978.

White, E., P. Sabbatini, M. Debbas, W.S.M. Wold, D.I. Kusher, and L. Gooding. 1992. The 19-kilodalton adenovinus E1B transforming protein inhibits programmed cell death and prevents cytolysis by tumor necrosis factor $\alpha$. Mol. Cell. Biol. 12: 2570-2580.

Whyte, P., K. Buchkovich, J.M. Horowitz, S.H. Friend, M. Raybuck, R.A. Weinbert, and E. Harlow. 1988. Association between an oncogene and an anti-oncogene: the adenovirus E1A proteins bind to the retinoblastoma gene product. $\mathrm{Na}$ ture 334: 124-129.

Wyllie, A.H. 1980. Glucocorticoid-induced thymocyte apoptosis is associated with endogenous endonuclease activation. Nature 284: 555-556.

Yew, P.R. and A.J. Berk. 1992. Inhibition of p53 transactivation required for transformation by adenovirus early $1 \mathrm{~B}$ protein. Nature 357: 82-85.

Yin, Y., M.A. Tainsky, F.Z. Bischoff, L.C. Strong, and G.M. Wahl. 1992. Wild-type p53 restores cell cycle control and inhibits gene amplification in cells with mutant p53 alleles. Cell 70: 937-948.

Yonish-Rouach, E., D. Resnitzky, J. Lotem, L. Sachs, A. Kimchi, and M. Oren. 1991. Wild-type p53 induces apoptosis of myeloid leukaemic cells that is inhibited by interleukin-6. $\mathrm{Na}$ ture 352: 345-347.

Zambetti, G.P., J. Baronetti, K. Walker, C. Prives, and A.J. Levine. 1992. Wild-type p53 mediates positive regulation of gene expression through a specific DNA sequence element. Genes \& Dev. 6: 1143-1152. 


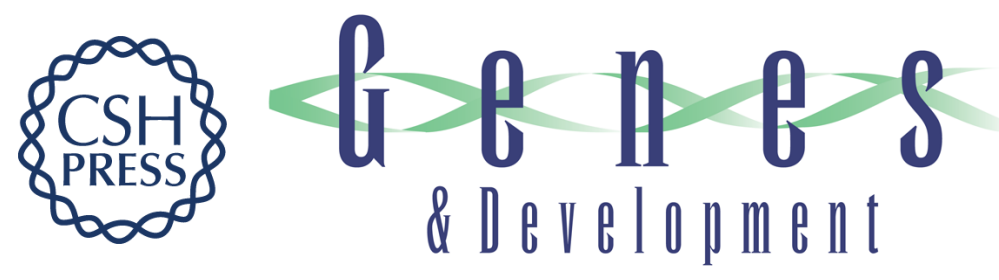

\section{Wild-type p53 mediates apoptosis by E1A, which is inhibited by E1B.}

M Debbas and E White

Genes Dev. 1993, 7:

Access the most recent version at doi:10.1101/gad.7.4.546 $\begin{array}{ll}\text { References } & \begin{array}{l}\text { This article cites } 63 \text { articles, } 28 \text { of which can be accessed free at: } \\ \text { http://genesdev.cshlp.org/content/7/4/546.full.html\#ref-list-1 }\end{array}\end{array}$

License

Email Alerting

Receive free email alerts when new articles cite this article - sign up in the box at the top Service right corner of the article or click here.

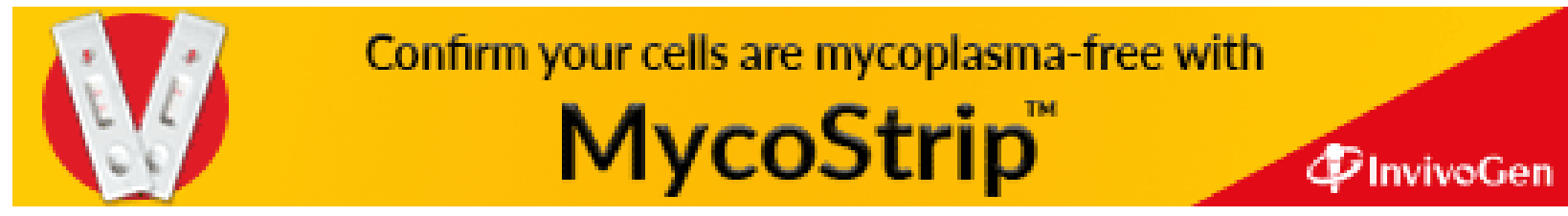

